\title{
Effects of Witch Hazel Oil on Damaged Hair
}

Ju-Sub Kim

Department of Beauty Design, Sangji University, Wonju-si, Gangwon-do, Korea

Corresponding author: Ju-Sub Kim, Department of Beauty Design, Sangji University, 84 Sangjidae-gil, Wonju-si, Gangwondo 26339, Korea

Tel.: +82 337300811

Fax: +82337300811

Email: c-miro@hanmail.net

Received September 02, 2021

Revised October 14, 2021

Accepted November 11, 2021

Published December 30, 2021

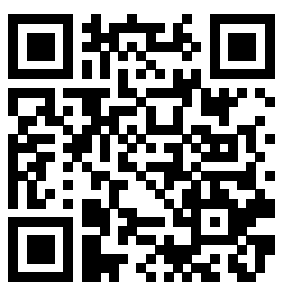

\begin{abstract}
Purpose: This study aims to investigate the effects of applying witch hazel oil on damaged hair. Methods: Adding 2, 4, and $6 \mathrm{~g}$ of witch hazel oil, applied to a sample of hairs bleached at level eight, produced formulations intended to enhance hair quality. This sample was compared with a cohort of damaged hair. Lightness $\left(\mathrm{L}^{*}\right)$ value was measured using a color meter to identify changes in the brightness of the hair sample. In addition, tensile strength, absorbance using methylene blue, and glossiness were measured to verify improvement in damaged hair. Results: The mean $L^{*}$ values of the hairs in the sample were higher when compared with those of healthy hair. However, this effect declined with increased oil dosage. Moreover, no statistically significant difference was observed between damaged hair and the sample. After applying the oil, the mean values for tensile strength in the sample increased in comparison with those of the hair in the damaged hair cohort. However, significant differences were noted for hairs $8 \mathrm{~L}(2), 8 \mathrm{~L}(4)$, and $8 \mathrm{~L}(6)$ from the sample. The mean values for absorbance decreased in all the hairs sampled, with significant differences noted for hairs $8 \mathrm{~L}(2), 8 \mathrm{~L}(4)$, and $8 \mathrm{~L}(6)$ from the sample. Another measure is glossiness, the mean values of which increased for hairs $8 \mathrm{~L}(2), 8 \mathrm{~L}(4)$, and $8 \mathrm{~L}(6)$ from the sample with significant differences. Conclusion: Significant differences in the mean values for tensile strength, absorbance, and glossiness were observed in hairs from the sample treated with varying doses of witch hazel oil, which indicates that the oil can improve the quality of damaged hair. However, we recommend that further studies be conducted to determine improvements in damaged hair using a variety of oils and natural extracts.
\end{abstract}

Keywords: Witch hazel oil, Hair, Improvement, Hair texture, Damage

\section{Introduction}

건강한 모발의 모표피는 편평하고 핵이 없는 세포로서 지붕 위의 기왓장을 겹친 모양을 하고 있고, 모발 내부의 보호막을 형성하고 있으면서 친유성으로 물과 약제의 침투에 저항력을 가지고 모피질 을 보호한다(Kim et al., 2010a). 또한 모피질은 피질섬유와 간충물 질, 핵의 잔사, 멜라닌으로 구성되어 있으며 친수성으로 약제의 작 용을 쉽게 받아 손상되기가 쉬우며 모발의 유연성, 탄력, 강도 등을 좌우한다(Kim et al., 2010b). 이러한 건강한 모발이 헤어스타일의 변화를 위한 화학적 작업으로 손상이 일어난다. 화학적 작업인 펌 제에 의해 모발은 모표피 층이 불규칙하게 쪼개져 떨어져 나갔고 규 티클과 규티클 사이가 들떠서 형태를 확인할 수 없을 정도로 손상이 된다(Sung \& Do, 2009). 탈색제를 도포하면 암모니아는 모발을 부
풀리고 과산화수소와 황산염은 산소를 방출시켜 멜라닌 색소를 산 화 탈색을 일으킨다(Kim, 2015). 탈색제의 주성분인 과산화수소가 모발의 세포막복합체 $(\mathrm{CMC})$ 에 화학적 변화를 일으키고, 지질 성분 의 용출을 촉진시켜서 외큐티클 층은 물론 내큐티클 층과 세포막에 까지 손상을 일으킨다(Lee \& Chang, 2008). 또한 변형된 케라틴 구 조에 높은 알칼리 사용과 반복적인 화학적 시술에 노출된 모발에 열 을 가하면 모발은 물리적으로 인장강도가 감소한다(Lee \& Chang, 2009). 이렇게 손상된 모발은 모표피가 박리 되고 모피질의 성분이 유실되어 탄력과 윤기, 인장강도가 감소되어 모발 손상을 더욱 가중 시킨다. 손상된 모발을 건강한 모발로 되돌릴 수는 없지만 최대한 제품력이나 작업 테크닉으로 모발 손상을 줄이고자 하는 노력이 이 루어지고 있다. 제품에 의한 노력은 모발의 질 개선 효과가 있을 것 으로 사료되는 천연 추출물, 오일 등에 대한 연구가 이루어 지고 있 
다. 이에 따른 연구로는 모발 염색 시술 시 오배자 추출물이 모발 에 미치는 효과(Lee \& Son, 2019), 땅콩 오일의 모질 개선 효과 연 구(Kim, 2020a), 피마자유가 탈색 모발의 모질 개선에 미치는 효과 (Kim, 2021a)등이 있다. 추출물과 오일에 대한 연구가 이루어지고 있지만 여전히 연구해야 할 성분 분야들이 다양하게 존재하고 있다. 이에 위치하젤(Witch hazel) 오일을 손상모발에 이용하여 모질 개선 효과가 있는지 알고자 하였다. 위치하젤은 수렴작용으로 피부에 신 선함을 주고 염증완화효과도 있고(Kim et al., 2017), 저항력을 강 화시키는 효과가 있기 때문에 기능성화장품으로 사용되기도 한다 (Ryu et al., 2008). 위치하젤의 효능인 수렴작용이 손상된 모발에 개선효과가 있을 것으로 사료되어 모발에 적용 연구하고자 하였다.

따라서 본 연구는 위치하젤 오일이 손상된 모발을 개선 하는 효 과가 있는지를 알아 보고자 하였다. 실험을 위해 위치하젤 오일을 함량 별로 다르게 사용하였고 도포력 향상을 위해 펌제이스제에 혼 합하여 제형제를 제조하였다. 제형제로 손상모와 위치하젤 오일을 첨가하여 도포한 시료를 비교 분석하였다. 비교 분석은 위치하젤 오일에 의해 모발의 명도 변화를 알아보고자 색차계 측정을 하였 고, 또한 모발의 강도 변화를 알기 위해 인장강도 측정을, 모발 성 분의 유실 정도를 알기 위해 메틸렌블루를 이용한 흡광도 측정, 모 발 표면 광택을 측정하여 손상된 모발의 개선 정도를 알아보고자 하였다.

\section{Methods}

\section{1. 실험 재료}

1) 시료 모발

실험에 사용된 모발은 최근 2 년 동안 화학적 시술을 하지 않은 18 세 여성의 모발을 후두부에서 두피 $3 \mathrm{~cm}$ 지점을 기준으로 20 $\mathrm{cm}$ 로 채취하여 $2 \mathrm{~g}$ 씩 모(hair) 다발을 만들었다. 플레인 린스 후 자연건조하여 사용하였다. 위치하젤 오일의 모발 손상 개선 정도를 연구하기 위하여 화학적시술을 전혀 하지 않은 건강모와 건강 모발 에 탈색제 제1제(ammonium persulfate, potassium persulfate, sodium metasilicate, magnesium, sodium carboxymethyl cellulose) (Suanhj, Korea) $3 \mathrm{mg}$ 과 제2제(6\%의 과산화수소 를 주성분으로 water, etidronic acid, phosphoric acid, sodium phosphate dibasic, cetyl alcohol로 구성된 제품) (Suanhj, Korea) $3 \mathrm{~mL}$ 를 1:1 비율로 혼합, 도포하고 $30 \mathrm{~min}$ 방치 후 세척하여 명도 8레벨 시료 4다발을 제작하였다. 실험에 사용된 모발 시료의 level 측정기(level scale, Wella, Germany)사용하여 측정하였다. 손상 모발과 손상 모발 시료에 각각 위치하젤 제형제로 상호 비교하였 다.

\section{2) 위치하젤 오일}

실험에 사용 한 위치하젤 오일은 화장품원료로 사용되는 오일로 코리아씨밀락(Korea Similac, Walterenterprise Co., Lt, Korea) 에서 구입하여 사용하였다.

\section{3) 모질 개선 제형제 제조}

실험에 사용한 모질 개선 제형제의 펌베이스제는 (주)수안향장 (Korea)에서 제조한 것으로 모든 제조에 사용하였으며, 펌베이스제 조성표는 Table 1과 같다. 이 펌 베이스제에 위치하젤 $2 \mathrm{~g}, 4 \mathrm{~g}, 6$ $\mathrm{g}$ 함량을 다르게 하여 혼합 제조였다.

\section{4) 측정기기 및 측정방법}

(1) 도포 전, 후의 명도 $\left(\mathrm{L}^{*}\right)$ 변화 측정

손상모와 함량 별로 위치하젤 오일이 함유된 제형제로 도포한 시 료의 표면 색상 변화를 알아보고자 색차계(Color meter, CR-400;

Table 1. Composition of perm-based agent

\begin{tabular}{|c|c|c|c|c|}
\hline No & Ingredients & Content (\%) & Content (kg) & Function \\
\hline 1 & Water & 89.850 & 89.850 & Solvent \\
\hline 2 & Tri ethanolamine & 0.150 & 0.150 & $\mathrm{Ph}$ adjuster \\
\hline \multirow{2}{*}{3} & Cetyl alcohol & \multirow{2}{*}{3.000} & 1.8 & Emulsion stabilizer \\
\hline & Ceteth-40 & & 1.2 & Surfactant \\
\hline \multirow{4}{*}{4} & Myristyl alcohol & \multirow{4}{*}{2.000} & 0.04 & Emulsion stabilizer \\
\hline & Cetyl alcohol & & 0.22 & Emulsion stabilizer \\
\hline & Stearyl alcohol & & 1.72 & Emulsion stabilizer \\
\hline & Arachidyl alcohol & & 0.02 & Emulsion stabilizer \\
\hline \multirow{3}{*}{5} & Stearic acid & & 0.44 & Surfactant \\
\hline & Palmitic acid & 1.000 & 0.55 & Surfactant \\
\hline & Myristic acid & & 0.01 & Surfactant \\
\hline 6 & Mineral oil & 4.000 & 4 & Conditioning agent \\
\hline
\end{tabular}


Konica Minolta, Japan)를 이용하여 CIELAB 표색계의 색상 값인 명도 지수 $\mathrm{L}^{*}$ 값을 측정 비교하였다.

측정값의 신뢰성을 높이기 위해 10 회 측정하여 최고 값과 최저 값을 제외한 8회의 측정 값으로 비교 분석하였다.

\section{(2) 인장강도 측정}

손상모와 함량 별로 위치하젤 오일이 함유된 제형제로 도포 한 시료의 인장강도를 측정 비교하였다. 측정 기기 (Digital force gauge, HF-20; Tripod, China)로 인장강도를 측정하였다. 측정 값의 신뢰성을 위하여 7회 측정 후 측정 값 중 최고 값과 최저 값을 제외한 5 회의 측정 값으로 비교 분석하였다.

(3) 메틸렌블루를 이용한 흡광도 측정

손상모와 함량 별로 위치하젤 오일이 함유된 제형제로 도포한 시료를 메틸렌블루(methylene blue)를 이용하여 흡광도를 측정 비교하였다. 모발의 외경은 마이크로미터(Quickmike, Mitutoyo) 를 이용하여 0.080-0.085 mm의 굵기 오차범위를 정하고 $4 \mathrm{~cm}$ 의 길이로 2 가닥 잘랐다. 자른 후 2 가닥의 모발을 tube에 넣은 후 $\mathrm{MB}$ solution에 담가 vortex mixer (Vortex genie 2, Scientific Industries, USA)를 이용하여 $10 \mathrm{~s}$ 동안 vortexing하였다. $50^{\circ} \mathrm{C}$ heat block (wise therm HB-48P; Daihan Scientific, Korea)에 서 $10 \mathrm{~min}$ 간 유지하여 $\mathrm{MB}$ solution을 흡착시키고, tube에 있는 2 가닥의 시료를 꺼내어 표면에 묻어있는 $\mathrm{MB}$ solution은 실험용 티 슈를 이용하여 제거하고, 시료 2 가닥을 각각 새 tube에 옮겨 담 았다. 이 tube에 NR desorb solution을 $5 \mathrm{~mL}$ 를 넣고 상온에서 5 $\min$ 방치 후 $10 \mathrm{~s}$ vortexing 후 추출하였다. 추출한 용액을 큐벳 (cuvettes)에 $3000 \mu \mathrm{L}$ 분주하여 $\mathrm{MB}$ 의 흡수 강도가 가장 높은 파 장인 $660 \mathrm{~nm}$ 로 흡광도를 측정하였다. 1 회 추출 후 같은 방법으 로 총2회 분광광도계(Vis spectrophotometer, SV1200; Azzota, $\mathrm{USA}$ )로 흡광도를 측정 총 4 회의 값으로 비교 분석하였다. 측정 시 기준 값을 잡기 위해 desorb solution을 $3000 \mu \mathrm{L}$ 분주하여 blank 를 만들어준다. $\mathrm{MB}$ 시약은 $\mathrm{DW} 20 \mathrm{~mL}+\mathrm{MB} 400 \mu \mathrm{L}$ 으로 희석 하여 $2 \%$ 로 만들어 사용하였다. NR solution은 $49 \%$ ethanol (49 $\mathrm{mL})+1 \%$ glacial aceticacid $(1 \mathrm{~mL})+50 \% \mathrm{DW}(50 \mathrm{~mL})$ 의 비율 로 완성하였다.
(4) 모발 표면 광택 측정

손상모와 함량 별로 위치하젤 오일이 함유된 제형제로 도포한 시료의 광택 변화를 알아보고자 광택계(Gloss meter NHG268; Shenzhen Threenh Technology, China)를 이용하여 측정 비교하 였다. 측정값의 신뢰성을 높이기 위해 10 회 측정하여 최고 값과 최 저 값을 제외한 8회의 측정 값으로 비교 분석하였다.

\section{5) 도포 실험방법}

도포 전 측정은 건강모 $(3 \mathrm{~g})$ 와 탈색으로 시술 한 모발 시료 8레 벨 시료 전체 다발 $(12 \mathrm{~g})$ 을 가지고 명도, 인장강도, 흡광도, 광택을 측정하였고, 도포 후 측정은 8레벨로 손상된 시료에는 위치하젤 오 일을 $2 \mathrm{~g}, 4 \mathrm{~g}, 6 \mathrm{~g}$ 첨가한 제형제로 각각의 시료에 $20 \mathrm{~g}$ 도포 후에 측정하였다. 도포한 후 열처리 $10 \mathrm{~min}$ 과 자연건조 $20 \mathrm{~min}$ 후에 세 척하여 자연건조 시켜 측정하였다. 시료에 도포는 도포량, 자연방 치시간, 열처리 시간, 시술자의 숙련도에 등에 따라서 측정에 차이 가 있을 수 있기 때문에 최대한 차이를 줄이기 위해 시술자는 각 단 계별로 동일인이 시술하였다. 각 위치하젤 오일의 함량에 따른 모 질 개선 제형제 시료 표기는 Table 2 와 같다.

Virgin hair는 건강모, 8L(0)시료는 bleach hair로 8레벨 시료, 8L(2) 시료는 8레벨시료에 위치하젤 오일 $2 \mathrm{~g}$ 과 펌베이스 $18 \mathrm{~g}$ 혼 합 도포, 8L(4) 시료는 8레벨시료에 위치하젤 오일 $4 \mathrm{~g}$ 과 펌베이스 $16 \mathrm{~g}$ 혼합 도포, 8L(6) 시료는 8레벨시료에 위치하젤 오일 $6 \mathrm{~g}$ 과 펌베이스 $14 \mathrm{~g}$ 혼합 도포하였다.

\section{6) 결과 분석}

각 항목의 실험은 명도 측정과 광택 측정은 8회, 인장강도는 5 회 측정, 흡광도는 4 회 측정한 값으로 손상모와 위치하젤 오일을 함 유한 제형제를 도포한 시료를 비교 분석하였다. 신뢰성과 객관성 을 높이기 위한 통계분석을 위해 평균(mean), 표준편차(standard division, $\mathrm{SD}$ )를 구하고 사후 검증으로 통계 프로그램인 jamovi 1.2.27 solid를 이용하여 $t$-tests (Independent sample $t$-test)로 실시하였고, 유의 수준은 $p<0.05$ 수준에서 검증하였다. 귀무가설은 "손상모와 오일을 함유한 제형제로 손상모에 도포한 시료가 차이가 없다" 이고 연구가설은 "손상모와 오일을 함유한 제형제로 손상모에 도포한 시료가 차이가 있다"로 하였다.

Table 2. Expression method for the samples

\begin{tabular}{ll}
\hline Sample & Virgin hair \\
Virgin hair & level-8 sample (Bleached hair) \\
$8 \mathrm{~L}(0)$ & Treatment of level-8 sample with Witch hazel oil $2 \mathrm{~g}$ and perm-base $18 \mathrm{~g}$ \\
$8 \mathrm{~L}(2)$ & Treatment of level-8 sample with Witch hazel oil $4 \mathrm{~g}$ and perm-base $16 \mathrm{~g}$ \\
$8 \mathrm{~L}(4)$ & Treatment of level-8 sample with Witch hazel oil $6 \mathrm{~g}$ and perm-base $14 \mathrm{~g}$ \\
$8 \mathrm{~L}(6)$ &
\end{tabular}




\section{Results and Discussion}

\section{1. 시료 별 명도 변화 측정}

건강모, 손상모와 위치하젤 오일을 첨가하여 제조한 제형제로 도 포한 시료 별 $\mathrm{L}^{*}$ 값 측정 결과는 Table 3 과 같다. $\mathrm{L}^{*}$ 은 밝기인 명도 (lightness)를 표현하는 수치로 0에서 100사이의 수치로 표시한다. 이때 0 은 black을 나타내고, 100 은 white를 나타낸다. 시료 별로 평 균의 차이가 표본을 추출 할 때 발생하는 표본 오차에 의한 차이인 지 아니면 모평균 차이에 의한 것이지 판단하기 위해 모든 비교 시료 를 $t$-검정을 통해 검정하였다. 건강모와 $8 \mathrm{~L}(0)$ 시료의 $\mathrm{L}^{*}$ 값 비교는 평 균값이 -33.0 차이를 보였고, 통계 결과 유의확률( $p$-value) 0.002 로 유의기준 $p<0.05$ 보다 작은 값으로 유의미한 결과를 알 수 있었 다. 건강모와 블리치 손상모인 $8 \mathrm{~L}(0)$ 의 명도 차이가 있는 것을 알 수 있었다. 이는 탈색을 하면 L"값이 증가한다(Kang, 2015)는 결과와 같음을 알 수 있었다. $8 \mathrm{~L}(0)$ 와 $8 \mathrm{~L}(2)$ 시료의 비교 결과 평균값의 차 이는 -11.2 로 $8 \mathrm{~L}(2)$ 의 값이 높았고, 통계 결과 유의확률이 0.158 로 유의기준 $p<0.05$ 보다 높아 유의미하지 않은 결과로 차이가 없음 을 알 수 있었다. $8 \mathrm{~L}(0)$ 와 $8 \mathrm{~L}(4)$ 시료의 비교 결과 평균값의 차이는 -7.8 로 $8 \mathrm{~L}(4)$ 의 값이 높았고, 통계 결과 유의확률이 0.303 으로 유 의기준 $\mathrm{p}\langle 0.05$ 보다 높아 유의미하지 않은 결과로 차이가 없음을 알 수 있었다. $8 \mathrm{~L}(0)$ 와 $8 \mathrm{~L}(6)$ 시료의 비교 결과 평균값의 차이는 -7.3 으로 $8 \mathrm{~L}(6)$ 의 값이 높았고, 통계 결과 유의확률이 0.337 로 유의기준 $p<0.05$ 보다 높아 유의미하지 않은 결과로 차이가 없음을 알 수 있었 다. 위치하젤 오일을 미처리한 $8 \mathrm{~L}(0)$ 시료와 오일을 첨가하여 제조한 제형제로 도포한 시료인 $8 \mathrm{~L}(2), 8 \mathrm{~L}(4), 8 \mathrm{~L}(6)$ 의 L'값 차이는 평균값 에서는 차이가 있었으나 통계적으로는 차이가 없음을 알 수 있었다. 평균값의 차이에서는 오일 함량이 많을수록 L"값이 낮아짐을 알 수 있었다. 이는 오트밀 오일 함량이 증가할수록 L ${ }^{*}$ 값이 감소한다(Kim, 2020b)는 결과와 같음을 알 수 있었다. 통계분석 결과 귀무가설이 채 택되고 연구가설이 기각되어 손상모와 오일을 함유한 제형제로 손상 모에 도포한 시료가 차이가 없음을 알 수 있었다. 이 결과로는 위치 하젤이 모발의 L*값에는 큰 변화를 주지 않음을 알 수 있었다.

\section{2. 시료 별의 인장강도 측정}

건강모, 손상모와 위치하젤 오일을 첨가하여 제조한 제형제로 도 포한 시료 별 인장강도 측정 결과는 Table 4 와 같다. 시료 별로 평균 의 차이가 표본을 추출 할 때 발생하는 표본 오차에 의한 차이인지 아 니면 모평균 차이에 의한 것이지 판단하기 위해 모든 비교 시료를 $t-$ 검정을 통해 검정하였다. 건강모와 $8 \mathrm{~L}(0)$ 시료의 인장강도 비교는 평 균값이 0.47 차이를 보였고, 통계 결과 유의확률( $p$-value) $\langle 0.001$ 로 유의기준 $p<0.05$ 보다 작은 값으로 유의미한 결과를 알 수 있었다. 건강모와 블리치 손상모인 $8 \mathrm{~L}(0)$ 의 인장강도 차이가 있는 것을 알 수 있었다. 이는 탈색한 모발의 인장강도가 감소하였다(Min et al., 2011)는 결과와 같음을 알 수 있었다. $8 \mathrm{~L}(0)$ 와 $8 \mathrm{~L}(2)$ 시료의 비교 결

\section{Table 3. $L^{*}$ value}

\begin{tabular}{lcccc}
\hline Sample & Mean & Mean difference & Statistic & $p$ \\
Virgin hair & 22.7 & -33.0 & 0.471 & $0.002^{*}$ \\
$8 \mathrm{~L}(0)$ & 55.7 & & 19.9 & 0.158 \\
$8 \mathrm{~L}(0)$ & 55.7 & -11.2 & 19.9 & 0.303 \\
$8 \mathrm{~L}(2)$ & 66.9 & -7.8 & 0.645 & 0.9 \\
$8 \mathrm{~L}(0)$ & 55.7 & & 19.9 & 0.352 \\
$8 \mathrm{~L}(4)$ & 63.5 & -7.3 & 19.9 & 0.337 \\
$8 \mathrm{~L}(0)$ & 55.7 & & 0.28 & \\
$8 \mathrm{~L}(6)$ & 63.0 & & & \\
\hline$p<0.05$ & & & & \\
\hline
\end{tabular}

Table 4. Tensile strength

(Unit: N)

\begin{tabular}{lcccc}
\hline Sample & Mean & Mean difference & Statistic & $p$ \\
Virgin hair & 1.59 & 0.47 & 0.063 & $<0.001^{*}$ \\
$8 \mathrm{~L}(0)$ & 1.12 & & 0.067 & $0.015^{*}$ \\
$8 \mathrm{~L}(0)$ & 1.12 & 0.10 & 0.067 & $<0.001^{*}$ \\
$8 \mathrm{~L}(2)$ & 1.22 & & 0.043 & $<0.001^{*}$ \\
$8 \mathrm{~L}(0)$ & 1.12 & -0.19 & 0.067 & $<$ \\
$8 \mathrm{~L}(4)$ & 1.31 & & 0.038 & $<$ \\
$8 \mathrm{~L}(0)$ & 1.12 & -0.30 & 0.067 & 0.036 \\
$8 \mathrm{~L}(6)$ & 1.42 & & & \\
\hline
\end{tabular}

${ }^{*} p<0.05$. 
과 평균값의 차이는 -0.10 으로 $8 \mathrm{~L}(2)$ 의 값이 높았고, 통계 결과 유 의확률이 0.015 로 유의기준 $\mathrm{p}<0.05$ 보다 낮아 유의미한 결과를 알 수 있어 인장강도 차이가 있음을 알 수 있었다. $8 \mathrm{~L}(0)$ 와 $8 \mathrm{~L}(4)$ 시료의 비 교 결과 평균값의 차이는 -0.19 로 $8 \mathrm{~L}(4)$ 의 값이 높았고, 통계 결과 유의확률이 $<0.001$ 로 유의기준 $p<0.05$ 보다 낮아 유의미한 결과를 알 수 있어 인장강도 차이가 있음을 알 수 있었다. $8 \mathrm{~L}(0)$ 와 $8 \mathrm{~L}(6)$ 시료의 비교 결과 평균값의 차이는 -0.30 으로 $8 \mathrm{~L}(6)$ 의 값이 높았고, 통계 결 과 유의확률이 〈0.001로 유의기준 $p<0.05$ 보다 낮아 유의미한 결과를 알 수 있어 인장강도 차이가 있음을 알 수 있었다. 위치하젤 오일을 미처리한 $8 \mathrm{~L}(0)$ 시료와 오일을 첨가하여 제조한 제형제로 도포한 시 료인 $8 \mathrm{~L}(2), 8 \mathrm{~L}(4), 8 \mathrm{~L}(6)$ 의 인장강도 차이는 평균값에서 차이가 있 었고, 통계적으로 귀무가설이 기각되고 연구가설이 채택되어 "손상 모와 오일을 함유한 제형제로 손상모"에 도포한 시료가 차이가 있음 을 알 수 있었다. 평균값의 차이에서는 오일 함량이 많을수록 인장강 도가 높아짐을 알 수 있었다. 이는 밍크오일 함량이 증가할수록 인장 강도가 증가한다 $(\mathrm{Kim}, 2020 \mathrm{c})$ 는 결과와 같음을 알 수 있었다. 통계 분석 결과로 위치하젤이 모발의 인장강도에 영향을 주어 모질 개선효 과가 있는 것을 알 수 있었다.

\section{3. 시료 별의 메틸렌블루를 이용한 흡광도 측정 결과}

건강모, 손상모와 위치하젤 오일을 첨가하여 제조한 제형제로 도 포한 시료 별 흡광도 측정 결과는 Table 5 와 같다. 시료 별로 평균의
차이가 표본을 추출 할 때 발생하는 표본 오차에 의한 차이인지 아니 면 모평균 차이에 의한 것이지 판단하기 위해 모든 비교 시료를 $t$-검 정을 통해 검정하였다. 건강모와 $8 \mathrm{~L}(0)$ 시료의 흡광도 비교는 평균값 이 -0.342 차이를 보였고, 통계 결과 유의확률( $p$-value) 0.013 으로 유의기준 $p<0.05$ 보다 작은 값으로 유의미한 결과를 알 수 있었다. 건 강모와 블리치 손상모인 $8 \mathrm{~L}(0)$ 의 흡광도 차이가 있는 것을 알 수 있 었다. 이는 탈색한 모발의 흡광도가 증가하였다(Oh \& Choe, 2012) 는 결과와 같음을 알 수 있었다. $8 \mathrm{~L}(0)$ 와 $8 \mathrm{~L}(2)$ 시료의 비교 결과 평 균값의 차이는 0.171 로 $8 \mathrm{~L}(2)$ 의 값이 낮았고, 통계 결과 유의확률이 $<0.001$ 로 유의기준 $p<0.05$ 보다 낮아 유의미한 결과를 알 수 있어 흡 광도 차이가 있음을 알 수 있었다. $8 \mathrm{~L}(0)$ 와 $8 \mathrm{~L}(4)$ 시료의 비교 결과 평균값의 차이는 0.219 로 $8 \mathrm{~L}(4)$ 의 값이 낮았고, 통계 결과 유의확률 이 $<0.001$ 로 유의기준 $p<0.05$ 보다 낮아 유의미한 결과를 알 수 있어 흡광도 차이가 있음을 알 수 있었다. $8 \mathrm{~L}(0)$ 와 $8 \mathrm{~L}(6)$ 시료의 비교 결 과 평균값의 차이는 0.259 로 $8 \mathrm{~L}(6)$ 의 값이 낮았고, 통계 결과 유의확 률이 $<0.001$ 로 유의기준 $p<0.05$ 보다 낮아 유의미한 결과를 알 수 있 어 흡광도 차이가 있음을 알 수 있었다. 위치하젤 오일을 미처리한 $8 \mathrm{~L}(0)$ 시료와 오일을 첨가하여 제조한 제형제로 도포한 시료인 $8 \mathrm{~L}(2)$, 8L(4), 8L(6)의 흡광도 차이는 평균값에서 차이가 있었고, 통계적으 로 귀무가설이 기각되고 연구가설이 채택되어 "손상모와 오일을 함유 한 제형제로 손상모"에 도포한 시료가 차이가 있음을 알 수 있었다. 평균값의 차이에서는 오일 함량이 많을수록 흡광도가 낮아짐을 알 수

Table 5. Optical density

(Unit: Abs)

\begin{tabular}{|c|c|c|c|c|}
\hline Sample & Mean & Mean difference & Statistic & $p$ \\
\hline Virgin hair & 0.084 & \multirow{2}{*}{-0.342} & 0.012 & \multirow{2}{*}{0.013} \\
\hline $8 \mathrm{~L}(0)$ & 0.426 & & 0.023 & \\
\hline $8 \mathrm{~L}(0)$ & 0.426 & \multirow{2}{*}{0.171} & 0.023 & \multirow{2}{*}{$<0.001$} \\
\hline $8 \mathrm{~L}(2)$ & 0.255 & & 0.020 & \\
\hline $8 \mathrm{~L}(0)$ & 0.426 & \multirow{2}{*}{0.219} & 0.023 & \multirow{2}{*}{$<0.001$} \\
\hline $8 \mathrm{~L}(4)$ & 0.207 & & 0.015 & \\
\hline $8 \mathrm{~L}(0)$ & 0.426 & \multirow{2}{*}{0.259} & 0.023 & \multirow{2}{*}{$<0.001$} \\
\hline $8 \mathrm{~L}(6)$ & 0.167 & & 0.009 & \\
\hline
\end{tabular}

${ }^{*} p<0.05$.

Table 6. Glossiness

(Unit: GU)

\begin{tabular}{lcccc}
\hline Sample & Mean & Mean difference & Statistic & $p$ \\
Virgin hair & 0.63 & -1.19 & 0.051 & $<0.001^{*}$ \\
$8 \mathrm{~L}(0)$ & 1.82 & & 0.116 & $<0.001^{*}$ \\
$8 \mathrm{~L}(0)$ & 1.82 & -0.24 & 0.116 & $<0.001^{*}$ \\
$8 \mathrm{~L}(2)$ & 2.06 & & 0.051 & $<.116$ \\
$8 \mathrm{~L}(0)$ & 1.82 & -0.63 & 0.107 & $<0.001^{*}$ \\
$8 \mathrm{~L}(4)$ & 2.45 & & 0.116 & 0.116 \\
$8 \mathrm{~L}(0)$ & 1.82 & -0.81 & & \\
$8 \mathrm{~L}(6)$ & 2.67 & & & \\
\hline
\end{tabular}

${ }^{*} p<0.05$. 
있었다. 통계분석 결과로 위치하젤이 모발의 흡광도에 영향을 주어 모질 개선효과가 있는 것을 알 수 있었다. 이는 윗점 오일을 첨가한 제형제가 흡광도에 영향을 주어 모질 개선효과가 있다(Kim, 2020d) 는 결과와 같음을 알 수 있었다.

\section{4. 시료 별의 광택 측정 결과}

건강모, 손상모와 위치하젤 오일을 첨가하여 제조한 제형제로 도 포한 시료 별 광택 측정 결과는 Table 6 과 같다. 시료 별로 평균의 차 이가 표본을 추출 할 때 발생하는 표본 오차에 의한 차이인지 아니 면 모평균 차이에 의한 것이지 판단하기 위해 모든 비교 시료를 $t-$ 검정을 통해 검정하였다. 건강모와 $8 \mathrm{~L}(0)$ 시료의 광택 비교는 평균값 이 -1.19 차이를 보였고, 통계 결과 유의확률( $p$-value) 〈0.001로 유 의기준 $p<0.05$ 보다 작은 값으로 유의미한 결과를 알 수 있었다. 건강 모와 블리치 손상모인 $8 \mathrm{~L}(0)$ 의 광택 차이가 있는 것을 알 수 있었다. $8 \mathrm{~L}(0)$ 와 $8 \mathrm{~L}(2)$ 시료의 비교 결과 평균값의 차이는 -0.24 로 $8 \mathrm{~L}(2)$ 의 값이 높았고, 통계 결과 유의확률이 〈 0.001 로 유의기준 $\mathrm{p}<0.05$ 보다 낮아 유의미한 결과를 알 수 있어 광택 차이가 있음을 알 수 있었다. $8 \mathrm{~L}(0)$ 와 $8 \mathrm{~L}(4)$ 시료의 비교 결과 평균값의 차이는 -0.63 으로 $8 \mathrm{~L}(4)$ 의 값이 높았고, 통계 결과 유의확률이 $\langle 0.001$ 로 유의기준 $p<0.05$ 보 다 낮아 유의미한 결과를 알 수 있어 광택 차이가 있음을 알 수 있었 다. $8 \mathrm{~L}(0)$ 와 $8 \mathrm{~L}(6)$ 시료의 비교 결과 평균값의 차이는 -0.81 로 $8 \mathrm{~L}(6)$ 의 값이 높았고, 통계 결과 유의확률이 $\langle 0.001$ 로 유의기준 $\mathrm{p}\langle 0.05$ 보 다 낮아 유의미한 결과를 알 수 있어 광택 차이가 있음을 알 수 있었 다. 위치하젤 오일을 미처리한 $8 \mathrm{~L}(0)$ 시료와 오일을 첨가하여 제조한 제형제로 도포한 시료인 $8 \mathrm{~L}(2), 8 \mathrm{~L}(4), 8 \mathrm{~L}(6)$ 의 광택 차이는 평균값 에서 차이가 있었고, 통계적으로도 차이가 있음을 알 수 있었다. 평 균값의 차이에서는 오일 함량이 많을수록 광택 값이 높아짐을 알 수 있었다. 통계적으로 귀무가설이 기각되고 연구가설이 채택되어 "손 상모와 오일을 함유한 제형제로 손상모"에 도포한 시료가 차이가 있 음을 알 수 있었다. 이결과 위치하젤이 모발의 광택에 영향을 주어 모질 개선효과가 있는 것을 알 수 있었다. 이는 닥나무추출물을 첨가 한 제형제가 광택에 영향을 주어 모질 개선효과가 있다(Kim, 2021b) 는 결과와 같음을 알 수 있었다.

\section{Conclusion}

본 연구는 손상된 모발의 개선 정도를 알기 위해 위치하젤 오일 성 분으로 제조한 제형제로 손상된 모발에 도포하여 개선 효과가 있는지 를 연구하였다. 모질 개선 효과를 알기 위해 위치하젤 오일을 $2 \mathrm{~g}, 4$ $\mathrm{g}, 6 \mathrm{~g}$ 으로 함량을 다르게 하여 모질 개선 제형제를 제조하여 도포하 였다. 시료 별 $\mathrm{L}^{*}$ 을 측정하여 위치하젤 오일에 의한 명도 변화를 비교 분석하였고, 손상된 모발 개선 효과를 알기 위해 모발 인장강도, 메
틸렌블루를 이용한 흡광도, 광태 측정을 하였다. 그 결과 다음과 같 은 결론을 얻었다.

첫째, 시료 별 명도 변화를 알기 위한 $\mathrm{L}^{*}$ 값 측정 결과 손상모에 도 포한 시료 평균값은 건강모 보다는 증가하고, 위치하젤 함량이 높을 수록 감소하였다. 통계분석 결과 $8 \mathrm{~L}(0)$ 시료와 비교한8L(2), $8 \mathrm{~L}(4)$, $8 \mathrm{~L}(6)$ 시료 모두 유의미하지 않은 결과로 차이가 없음을 알 수 있었 다.

둘째, 인장강도 측정 결과 시료 별의 인장강도 측정결과 손상모에 도포한 시료 평균값은 건강모 보다는 감소하고, 위치하젤 함량이 높 을수록 증가하였다. 통계분석 결과 8L(0)시료와 비교한8L(2), 8L(4), $8 \mathrm{~L}(6)$ 시료 모두 유의미한 결과로 인장강도 차이가 있어 개선효과가 있음을 알 수 있었다.

셋째, 메틸렌블루를 이용한 흡광도 측정 결과 손상모에 도포한 시 료 평균값은 건강모 보다는 증가하고, 위치하젤 함량이 높을수록 감 소하였다. 통계분석 결과 $8 \mathrm{~L}(0)$ 시료와 비교한8L(2), $8 \mathrm{~L}(4), 8 \mathrm{~L}(6)$ 시 료 모두 유의미한 결과로 흡광도 차이가 있어 개선효과가 있음을 알 수 있었다.

넷째, 광택 측정 결과 평균값은 결과 손상모에 도포한 시료 평균값 은 건강모 보다는 증가하고, 위치하젤 함량이 높을수록 증가하였다. 통계분석 결과 $8 \mathrm{~L}(0)$ 시료와 비교한 $8 \mathrm{~L}(2), 8 \mathrm{~L}(4), 8 \mathrm{~L}(6)$ 시료 모두 유 의미한 결과로 광택 차이가 있어 개선효과가 있음을 알 수 있었다.

이와 같은 결과로 천연 위치하젤 오일이 첨가된 제형제가 손상된 모발에 모질 개선효과가 있는지 연구한 결과 오일을 첨가한 제형제로 도포한 시료에서 $\mathrm{L}^{*}$ 값을 제외한 인장강도, 흡광도, 광택에 있어 평 균값이 차이가 나고 통계분석결과도 차이가 있어 모질 개선 효과가 있음을 알 수 있었다. 이로 인해 위치하젤오일이 모질개선제 성분으 로 상용화 할 수 있는 가능성을 제시 할 수 있었다. 차후 다양한 종류 의 오일류, 천연 추출물에 의한 모발 개선 효과 연구가 필요하고, 실 험 측정 방법과, 처치 방법의 다양화가 필요하겠다.

\section{Author's contribution}

JK designed all experimental investigations, collected witch hazel oil data, and wrote the manuscript.

\section{Author details}

Jusub Kim (Professor), Department of Beauty Design, Sangji University, 84 Sangjidae-gil, Wonju-si, Gangwondo 26339, Korea.

\section{References}

Kang EN. Effects of hair treatment for bleaching on hair color. 
Journal of the Korean Society of Beauty and Arts, 16: 5159, 2015.

Kim JS, Kim CS, Kim YJ, You SE. Hair science. Hunminsa, Seoul, p68-69, 2010a.

Kim JS, Kim CS, Lim DJ, Choi EJ, Jang HE, Shin JE. Scalp \& hair management. Kuhminsa, Seoul, p31-32, $2010 b$.

Kim JS. The effects that the moisture content affects hair damaging when bleach. Journal of the Beauty Art Management, 9: 35-41, 2015.

Kim JS, Shin HC, Kim GH. Hair cosmetics materials. Kuhminsa, Seoul, p151, 2017.

Kim JS. Effect of peanut oil on hair texture improvement. Asian Journal of Beauty and Cosmetology, 18: 331-340, 2020a.

Kim JS. Effect of oatmeal oil on hair texture improvement. Asian Journal of Beauty and Cosmetology, 18: 599-608, $2020 b$.

Kim JS. Effects of mink oil on improving hair texture. Journal of the Korean Applied Science and Technology, 37: 12981305, 2020c.

Kim JS. Effect of wheat germ oil on hair texture improvement. Asian Journal of Beauty and Cosmetology, 18: 609-618, 2020d.

Kim JS. Effects on the hair texture improvement of bleach hair in case when applying castor oil. Journal of The Korean Society of Cosmetology, 27: 89-96, 2021a.

Kim JS. Effect of paper mulberry extract on damaged hair.
Asian Journal of Beauty and Cosmetology, 19: 175-182, 2021b.

Lee BR, Son JY. A study on the effects of Galla chinensis exract on hair during hair dye. Journal of the Korean Society of Beauty Cultural Arts, 8: 57-65, 2019.

Lee GY, Chang BS. Electron microscopic studies on the morphological differences of ethnic hair. Korean journal of microscopy, 38: 265-273, 2008.

Lee WK, Chang BS. Morphological changes of pre-astronaut's hair during spaceflight training: a case report. Korean Journal of Microscopy, 39: 365-371, 2009.

Min MJ, Na MS, Ryu EM, Cha WS. Gray mullet extract on physical damage of colored and bleached hair. Asian Journal of Beauty and Cosmetology, 9: 1-9, 2011.

Oh MS, Choe TB. Determination of hair damage index using methylene blue staining method. Journal of The Korean Society of Cosmetology, 18: 531-537, 2012.

Ryu SY, Ahn HJ, Kwon JS, Park JH, Kim JY, Choi JH. The antibacterial effect of Witch Hazel (Hamamelis virginiana) on oral pathogens. Korean Journal of Oral Medicine, 33: 159166, 2008.

Sung KH, Do JY. A study of structural change of hair according to $\mathrm{pH}$ of permanenet wave lotions and hair textures. Journal of the Korean Society of Beauty and Arts, 27: 127$144,2009$. 


\section{국문초록}

\section{위치하젤 오일의 손상모발 개선효과}

김주섭

상지대학교 뷰티디자인학과, 강원도 원주시, 한국

목적: 본 연구는 위치하젤 오일로 손상된 모발에 도포하여 개선 효과를 알아보고자 하였다. 방법: 위치하젤 오일 함량을 $2 \mathrm{~g}, 4 \mathrm{~g}, 6$ $\mathrm{g}$ 을 첨가하여 모질 개선 제형제를 제조하였다. 제조한 제형제로 8 레벨로 탈색한 시료 모발에 도포하였다. 오일을 첨가한 제형제로 도포한 시료와 손상모를 측정하여 비교 분석하였다. 모발의 명도 변화를 알기 위해 색차계를 이용하여 $\mathrm{L}^{*}$ 값을 측정하였다. 또한 손 상된 모발 개선 효과를 알기 위해 모발의 인장강도, 메틸렌블루를 이용한 흡광도, 광택을 측정하였다. 결과: 시료 별 평균값 $\mathrm{L}^{*}$ 값 은 건강모보다 증가, 함량이 높을수록 감소하였다. 통계 결과 손상모와 다른 시료는 차이가 없었다. 인장강도 측정결과 평균값은 손 상모보다 오일을 첨가하여 도포한 8레벨 시료 모두 증가하였다. 통계 결과는 손상모와 비교 시 8L(2), 8L(4), 8L(6)시료 모두 차이가 있었다. 흡광도 측정결과 평균값은 손상모 보다는 오일을 첨가하여 도포한 8레벨 시료 모두 감소하였다. 통계 결과는 손상모와 비 교 시 8L(2), 8L(4), 8L(6)시료 모두 차이가 있었다. 광택 측정결과 평균값은 손상모와 비교 시8L(2), 8L(4), 8L(6) 시료 모두 증가하 였다. 통계 결과는 손상모와 비교 시 8L(2), 8L(4), 8L(6)시료 모두 차이가 있었다. 결론: 손상모와 오일을 첨가하여 도포한 시료의 평균값과 통계분석결과 인장강도, 흡광도, 광택의 차이를 보였다. 위치하젤 오일이 손상된 모발에 모질 개선 효과가 있는 것을 알 수 있었다. 차후 다양한 오일류, 천연 추출물에 의한 손상 모발 개선 효과 연구가 필요하다.

핵심어: 위치하젤오일, 모발, 개선, 모질, 손상

\section{참고문헌}

강은란. 모발 탈색 시 트리트먼트 처리에 따른 색차의 변화 연구. 한국인체미용예술학회지, 16: 51-59, 2015.

김종선. 탈색 시술시 수분함유량이 모발 손상에 미치는 영향. 미용예술경영연구, 9: 35-41, 2015.

김주섭, 김찬수, 김유정, 유세은. 모발과학. 훈민사, 서울, p68-69, 2010a.

김주섭, 김찬수, 임대진, 최은정, 장현희, 신지은. 두피모발관리학. 구민사, 서울, p31-32, 2010b.

김주섭, 신홍철, 김건희. 모발화장품성분학. 구민사, 서울, $\mathrm{p} 151,2017$.

김주섭. 땅콩오일의 모질 개선효과연구. 아시안뷰티화장품학술지, 18: 331-340, 2020a.

김주섭. 오트밀 오일의 모질개선효과. 아시안뷰티화장품학술지, 18: 599-608, $2020 \mathrm{~b}$.

김주섭. 밍크오일의 모질 개선효과. 한국응용과학기술학회지, 37: 1298-1305, 2020c.

김주섭. 윗점오일의 모질 개선효과 연구. 아시안뷰티화장품학술지, 18: 609-618, $2020 \mathrm{~d}$.

김주섭. 피마자유가 탈색모발의 모질개선에 미치는 효과. 한국미용학회지, 27: 89-96, 2021a.

김주섭. 닥나무추출물에 의한 손상모발의 개선효과. 아시안뷰티화장품학술지, 19: 175-182, $2021 \mathrm{~b}$.

류성용, 안현준, 권정승, 박주현, 김재영, 최종훈. Witch hazel (Hamamelis virginiana)의 구강병원균에 대한 항균효과.

대한안면통증구강내과학회지, 33:159-166, 2008.

민명자, 나명순, 류은미, 차월석. 숭어추출물이 염색과 탈색 모발의 물리적 손상에 미치는 영향. 아시안뷰티화장품학술지,

9: $1-9,2011$.

성경화, 도주연. 펌제의 $\mathrm{pH}$ 와 모질의 종류에 따른 모발구조 변화 연구. 한국인체미용예술학회지, 27: 127-144, 2009.

오명숙, 최태부. Methylene Blue 염색법을 이용한 모발손상지수의 결정. 한국미용학회지, 18: 531-537, 2012.

이귀영, 장병수. 인종 모발의 형태학적차이에 관한 전자현미경적 연구. 한국현미경학회지, $38: 265-273,2008$.

이보림, 손지연. 모발 염색 시술시 오배자 추출물이 모발에 미치는 효과. 대한미용문화예술학회지, 8: 57-65, 2019. 
이원근, 장병수. 우주비행훈련기간에 채취한 예비 우주인 모발의 형태적인변화. 한국현미경학회지, 39: 365-371, 2009. 


\section{中文摘要}

\section{金缕梅油对受损头发的影响}

金周䛓

尚志大学美容学科, 江原道原州市, 韩国

目的: 探讨金缕梅油对受损头发的影响。方法: 添加 2、4 和 6 克金缕梅油，应用于以 8 级漂白的头发样品，制 备旨在提高头发质量的配方。该样品与一组受损头发进行了比较。使用色度计测量亮度 ( $\mathrm{L}^{*}$ ) 值以识别头发样品 亮度的变化。此外, 还测量了拉伸强度、使用亚甲蓝的吸光度和光泽度, 以验证受损头发的改善。结果: 与健康 头发相比, 样品中头发的平均 $\mathrm{L}^{*}$ 值更高。然而, 这种效果随着油剂量的增加而减弱。此外, 在受损的头发和样 品之间没有观察到统计学上的显着差异。涂抹油后, 与受损头发群中头发的拉伸强度平均值相比, 样品中的拉 伸强度平均值增加。然而, 注意到样品中毛发 $8 \mathrm{~L}(2) 、 8 \mathrm{~L}(4)$ 和 $8 \mathrm{~L}(6)$ 存在显着差异。在所有采样的头发中, 吸 光度的平均值均下降, 从样品中注意到头发 $8 \mathrm{~L}(2) 、 8 \mathrm{~L}(4)$ 和 $8 \mathrm{~L}(6)$ 的显着差异。另一个衡量标准是光泽度, 样本 中毛发 $8 \mathrm{~L}(2) 、 8 \mathrm{~L}(4)$ 和 $8 \mathrm{~L}(6)$ 的平均值增加, 具有显着差异。结论: 在用不同剂量金缕梅油处理的样品中观察到 的头发的拉伸强度、吸光度和光泽度的平均值存在显着差异, 这表明该油可以改善受损头发的质量。然而, 我 们建议进行进一步的研究, 以确定使用各种油和天然提取物对受损头发的改善。

关键词: 金缕梅油, 头发, 改善, 头发质地, 损伤 